\title{
Available Resources and Laboratory/Workshop Practices as a Correlate Between Electrical Installation and Maintenance Work Students Behaviour and Entrepreneurial Intentions
}

\author{
Shodipe Olabanji T. ${ }^{1}$ Nwahunanya Innocent ${ }^{2}$ Martins Rebecca O. ${ }^{3}$ Abiodun Oluwasegun S. ${ }^{3}$ \\ ${ }^{1}$ Faculty of Vocational Technical Education, University of Nigeria, Nsukka. \\ ${ }^{2}$ Dept. Mechanical Engineering, Federal University of technology, Owerri. \\ ${ }^{3}$ School of Technical Education, Yaba College of Technology, Yaba, Lagos.
}

\begin{abstract}
Many graduates of Technical Colleges do not have intention to establish and run their own businesses which has caused a spike in the increase of unemployed persons in the society. Venturing into business may not necessarily solve these problems of unemployment but venturing into the right business with the right skill. To reduce the problems of unemployment EIMW students should have a desire to start a business enterprise for the purpose of making a profit. To achieve the purpose of the study, six hypotheses were formulated. Two hundred EIMW students were selected as sample using the multistage sampling technique. The data collected were analyzed using correlation and regression analysis. The result of the study showed that independent variables have significant influence on the dependent variable, thereby, the null hypotheses were rejected. It was concluded that available resources and laboratory/workshop practices have significant influence on the electrical installation and maintenance work students' entrepreneurial intentions. The result of this study will help to change the societal misconceptions about technical education entrepreneurs.
\end{abstract}

Keyword:- Resources, guided maintenance, safety practices and education, students behaviour, entrepreneurial intentions

\section{INTRODUCTION}

Many graduates of Technical Colleges do not have intention to establish and run their own businesses. This has resulted in many of them joining the number of unemployed persons in the society. Unemployment has remained a major problem in many parts of the world especially Africa. The level of unemployment has continued to rise in most African countries especially, Congo, Namibia, South Africa, Lesotho, Swaziland, Mozambique, Nigeria, among others. According to Trading Economics (2019), Nigeria is ranked seventh in Africa on the level of unemployment with 23.1 percent unemployed persons in the population as of September 2018. This problem has affected many Nigerian youths, especially those between 15 and 30 years. In the quest for jobs, very many venture into opportunities available to them without considering the skills required to meet up with the job requisites. Some venture into businesses that they were not vast in, in the end, it crumbled. Venturing into business may not necessarily solve the problems of unemployment but venturing into the right business with the right skill, knowledge, enthusiasm, and the ability to bear the impending risks which are the characteristics of an entrepreneur. The high level of unemployment among the youths requires urgent attention to entrepreneurship. Entrepreneurship could be defined as establishing and running a business. Entrepreneurship is an innovative and creative process where there is potential to add value to products, create job opportunities, raise productivity, revitalize and diversify markets, improve social welfare, and more broadly to develop the economy (Guerrero, Rialp \& Urbano, 2008).

Entrepreneurship as the spirit of entrepreneurial persons is an opportunity to discover any new business and dedicated to it so as to make a profit. Creating your business is becoming the order of the day in the economic retarding nations. According to Holmgren and From (2005) entrepreneurship has long been considered as a way to spur innovation and technological progress, engender competition, and create employment, leading to economic growth and national prosperity. Ozaralli and Rivenburgh (2016) noted that developing countries now adopt entrepreneurship as a means to stir socio-economic development and boost national wealth. Entrepreneurship could be defined as the recognition and exploitation of opportunities that result in the creation of a firm (Aragon Sanchez, Baixauli - Soler \& Carrasco - Hernadez, 2017). But Gartner (1989) owns a point that entrepreneurship could better be understood when a choice is included and the ability to bear the risk. Entrepreneurship is seen as prominent leverage of economic growth and success. It is believed that entrepreneurship benefits society: by recognizing business opportunities and generating ideas and resources that are used in developing the design of novel product and services or by raising the efficiency of existing products and services (Armstrong \& Hird 2009; Baron 2004). Therefore, to promote the entrepreneurship of graduates and drive the employment by entrepreneurship, it is necessary to explore the entrepreneurial intentions of 
undergraduate students, graduates and their influencing factors (Peng, Lu \& Kang, 2012).

Entrepreneurial intention is the desire to start a business enterprise for the purpose of making a profit and reducing unemployment in the society. Entrepreneurial intention can be defined as conscious awareness and conviction by an individual that they intend to set up a new business venture and plans to do so in the future (Thompson, 2009). Therefore, the process of starting a new firm can thus be regarded as voluntary with conscious intentionality. Entrepreneurial intention is based on the theory of planned behaviour by Ajzen (1991) which views intention as the best predictor of behaviour. Entrepreneurial intention is the thought/dream to own and run a new business venture. Hattab (2014) defined entrepreneurial intention as a state of mind which potentially fosters entrepreneurial action/behaviours in individual. It is the motivation/desire to establish and run a business venture (Ohanu \& Ogbuanya, 2018). Entrepreneurial intention model is used by several researchers to explain the effect of exogenous factors on intentions. This theory, unlike other theories, takes cognizance of the influence of resources (human, financial, materials, etc) on entrepreneurial behaviours (Krueger \& Carsrud, 1993). This theory explains the landslide effect of environmental factors on entrepreneurial attitude, subjective norm and perceived behavioural control to starting up a new business.

Based on the theory of planned behaviour (TPB), intention is the best predictor of behaviour. Gupta, Turban, Wasti \& Sikdar (2019) described intention to start a new business as the key behind entrepreneurial behaviour. $\mathrm{He}$ noted that there are three factors which determine the intentions: subjective norms, attitude and perceived behavioural control. These are the antecedents of entrepreneurial behaviour. The survival, growth and return factor in terms of profitability is the key decision to research over access to financial, human and that of social resources. Hence, access to the resources affects the entrepreneurial intentions which include possession or control to resources. It creates the need to study the link between the determinants of entrepreneurial intentions and the access to human, financial and resources through antecedents of entrepreneurial behaviour.

Students of Electrical Installation and Maintenance Works (EIMW) are supposed to have the intention of becoming entrepreneurs who will drive them to establish their own entrepreneurial outfits upon graduation Electrical Installation and Maintenance Works (EIMW) is an area of specialization in Technical Vocational Education and Training programme of technical colleges in Nigeria. It is designed to impart knowledge and practical skills in the areas of house wiring (conduit and surface), coil winding and re-winding, electrical gadgets repairs, installation and maintenance of electrical machines, battery charging, installation and maintenance of electric motors, among others. The EIMW programme is one of the Technical Vocational Education and Training (TVET) programmes which provides training leading to the production of craftsmen and technicians who could either secure employment at the end of their training, set up their own businesses or further their studies in Polytechnics, Colleges of Education (Technical) and Universities (National Board for Technical Education, NBTE, 2003). EIMW students are expected to acquire practical knowledge and skills which will enable them to establish their businesses and become entrepreneurs, instead of waiting for an employment opportunity.

Technical colleges are institutions established to impart knowledge and practical skills in different areas of Vocational and Technical Education such as Bricklaying, Block laying and Concreting, Plumbing and Pipe-fitting, Radio, Television and Electronics Works, Welding and Fabrication, Motor Vehicle Mechanics Works, Furniture Craft Practice, Agric Implements Mechanics, Printing Craft, Painting and Decorating, Refrigeration \& Air Conditioning as well as Electrical Installation and Maintenance Works. Federal Republic of Nigeria (2004) defined technical and vocational education as a comprehensive term referring to those aspects of the educational process involving in addition to general education the study of technologies and related sciences and the acquisition of practical skills, attitudes, understanding and knowledge relating to occupations in various sectors of economic and social life. Ohanu \& Chukwuone (2018) stated that Technical Education (TE) is provided to impart technical/occupational skills in the areas of electricity, electronics, metalwork, woodwork, automobile, and so on. Graduates of technical education are expected to acquire knowledge and skills in any of the trades in the above mentioned areas and become entrepreneurs instead of waiting for white collar jobs. It is expected that graduates of Electrical Installation and Maintenance Work from technical colleges should be able to develop business venture creation behaviour. This behaviour unlike a general behaviour will enable them establish an enterprise that will take up either sales or servicing of electrical accessories, electrical machines and general maintenance of electrical equipment.

\section{$>$ Statement of the Problem}

Electrical installation and maintenance work is one of the courses offered in technical colleges in Nigeria with the sole aim of building students to be self-employed and/or employers of labour. it is a three year programme offered in technical colleges with some months internship to be acquainted with the industrial experience. At the end, graduates of EIMW are supposed to become gainfully employed, sole proprietors and employers of labour with access to the required resources to thrive in the competitive labour market.

Despite the rigorous entrepreneurial training process in technical colleges, many of the Electrical Installation and Maintenance Work students roam the street in search of blue collar jobs in industries backsliding from the core objectives of entrepreneurial education and training received. Some of the employed ones are subjected to nonconducive service conditions and different work hazards as 
against the normal working conditions. Some settle for less pay as against the daily work period which implies that they work more and paid less for the services rendered.

Many EIMW students do not have the intention to become entrepreneurs or rather some lost their pursuit to become entrepreneurs. The common reason is adduced to the fact that small and medium enterprises or individuals in the country do not have access to the required resources to meet up with the job creation, production of goods and services and promotion of local contents (Eriki \& Anthony, 2009).

The general purpose of the study is to investigate available resources and laboratory/workshop practices as a correlate between Electrical Installation and Maintenance Work students' behaviour and entrepreneurial intentions. This study sought to identify different behavioural factors that will be exhibited to enhance the establishment of businesses with the availability of necessary school resources in a viable entrepreneurial environment. It appears that these factors influence entrepreneurial intentions among several categories of people but this study intends to find out the influence among Electrical Installation and Maintenance Work in technical colleges in Lagos State. Previous studies have divergent opinions and have researched into other variables that stimulate entrepreneurial intentions and some researchers used students from other relevant fields as sample for the study (Marjan, Ute, Mariola and Juan, 2017; Ana, Makedonka and Jadranka, 2016; Mumtaz, Munirah and Halimahton, 2012) but this study focused solely on available school resources and laboratory/workshop practices as variables.

\section{$>$ Hypothesis}

The following null hypotheses were tested at 0.05 significant level:

- There is no significant influence of EIMW students' safety practices and education, their attitude, subjective norms and perceived behavioural control on entrepreneurial intentions to start a new business.

- There is no significant influence of EIMW students' guided maintenance operations, their attitude, subjective norms and perceived behavioural control on entrepreneurial intentions to start a new business.

- There is no significant influence of EIMW students' access to human resources, their attitude, subjective norms, perceived behavioural control on entrepreneurial intentions to start a new business.

- There is no significant influence of EIMW students' access to financial resources, their attitude, subjective norms, perceived behavioural control on entrepreneurial intentions to start a new business.

- There is no significant influence of EIMW students' access to tools and equipment, their attitude, subjective norms, perceived behavioural control on entrepreneurial intentions to start a new business.

- There is no significant influence of EIMW students' access to material resources, their attitude, subjective norms, perceived behavioural control on entrepreneurial intentions towards starting a new business.

\section{METHODOLOGY}

\section{$>$ Design of the study \\ The design adopted for this study is the descriptive} survey research design.

\section{Sample and sampling techniques}

The sample used for the study is 200 EIMW students from the six technical colleges in Lagos state, south west Nigeria. The study involved a multistage sampling technique to select the sample. Multistage sampling entails two or more stages of random sampling based on the hierarchical randomly sampled at each stage with the cluster nested within each other at successive stage. The final stage of the sampling involves choosing random sample of people in the clusters selected at the penultimate stage (Sedgwick, 2015).

\section{Instrument for data collection}

The instrument used for data collection was a structured questionnaire that was based on two segments. The first segment were measured with a Likert seven (7) point scale of strongly agree, agree, somewhat agree, neither agree nor disagree, somewhat disagree, disagree and strongly disagree to access students intention of becoming an entrepreneur, ranging with scores of 1(lowest measure) to 7 (highest measure) while the other segment comprising safety practice and education and guided maintenance operations were measured on a 5 point Likert scale.

\section{Validation of the instrument}

Three experts from the Faculty of Vocational Technical Education, University of Nigeria, Nsukka validated the instrument. Corrections were based on the content structure of the instrument.

\section{$>$ Reliability of the instrument}

Cronbach alpha method was used in determining the internal consistency of the instrument. The validated instrument was tested on twenty (20) electrical installation and maintenance work students of Yaba College of Technology Secondary School, Yaba which were not part of the population. The reliability coefficient for safety practice and education is 0.7 , guided maintenance operations is 0.6 , access to human resource is 0.5 , access to financial resources is 0.6 , access to tools and equipment is 0.7 , access to materials 0.7 and entrepreneurial intentions is 0.8 .

\section{$>$ Method of data collection}

The data were collected by directly administering the instrument to the learners with the assistance of the school counselor. 


\section{Method of data analysis}

The analysis of the data was done using statistical package for social science (SPSS) version 23. The null hypotheses were tested using Pearson correlation and regression analysis

\section{RESULT OF THE STUDY}

Table 1 indicated the correlation, Means and standard deviation of the dependent variable and its relationships with the independent variables. Electrical installation and maintenance work students' safety practices and education had a low mean response rating; this may be accorded to the negative statements in the items of the instrument for data collection which does not reveal the actual image of the school laboratory/workshop environment. This therefore causes an insignificant influence with their entrepreneurial intentions. Also, available materials used for practical activities in the workshop showed a negative but significant influence with their entrepreneurial intentions while other variables had a significant positive influence on their entrepreneurial intentions.

\begin{tabular}{|c|c|c|c|c|}
\hline S/N & Independent variables & Mean & SD & Dependent variable \\
\hline 1 & Safety practices and education & 2.68 & 0.378 & 0.063 \\
\hline 2 & Guided maintenance operations & 4.03 & 0.471 & $0.198^{* *}$ \\
\hline 3 & Financial resources & 5.66 & 1.181 & $0.326^{* *}$ \\
\hline 4 & Human resources & 5.56 & 1.616 & $0.211^{* *}$ \\
\hline 5 & Material resources & 4.74 & 1.184 & $-0.145^{*}$ \\
\hline 6 & Tools and equipment & 5.97 & 0.961 & $0.341^{* *}$ \\
\hline 7 & Attitude & 5.83 & 0.889 & $0.468^{* *}$ \\
\hline 8 & Subjective norms & 5.35 & 1.516 & $0.146^{*}$ \\
\hline 9 & Perceived behavioural control & 5.82 & 0.777 & $0.373^{* *}$ \\
\hline 10 & Entrepreneurial intentions & \multicolumn{2}{|c|}{5.06} & 1.062 \\
\hline
\end{tabular}

Table 1:- Correlation analysis between the variables

The regression analysis in table 2 showed the predictions between the independent variables and the dependent variables. They are used to make a decision either to reject or accept the null hypothesis. The result of the study showed that guided maintenance operations, materials resources, and tools and equipment have a significant direct influence with entrepreneurial intentions. These variables have percentage influence range from $27.2 \%$ to $27.9 \%$, but all the resources have a significant influence with the mediating variables of attitude, subjective norms and perceived behavioural control. Therefore, the null hypotheses are rejected while the alternative hypotheses are accepted. Hence, available school resources and workshop practices have significance influence on attitude, subjective norms and perceived behavioural control on entrepreneurial intentions towards starting a new business.

\begin{tabular}{|c|c|c|c|c|c|c|c|c|}
\hline \multirow[t]{3}{*}{$\mathbf{S} / \mathbf{N}$} & \multirow[t]{3}{*}{ Independent variables } & \multicolumn{6}{|c|}{ Independent variables } & \multirow[t]{3}{*}{$\mathbf{P}$} \\
\hline & & \multicolumn{2}{|c|}{ AT } & \multicolumn{2}{|c|}{ SN } & \multicolumn{2}{|c|}{ PBC } & \\
\hline & & B & $\mathbf{T}$ & $\boldsymbol{\beta}$ & $\mathbf{t}$ & $\beta$ & $\mathbf{t}$ & \\
\hline 1 & $\begin{array}{l}\text { Safety practices and education } \\
\mathrm{R}^{2}=0.253, \mathrm{p}=0.503\end{array}$ & 0.377 & 5.575 & 0.002 & 0.029 & 0.198 & 2.901 & 0.000 \\
\hline 2 & $\begin{array}{l}\text { Guided maintenance operations } \\
\qquad \mathrm{R}^{2}=0.272, \mathrm{p}=0.016\end{array}$ & 0.370 & 5.539 & -0.003 & -0.046 & 0.189 & 2.808 & 0.000 \\
\hline 3 & $\begin{array}{c}\text { Financial resources } \\
\mathrm{R}^{2}=0.263, \mathrm{p}=0.070\end{array}$ & 0.335 & 4.728 & -0.008 & -0.134 & 0.182 & 2.657 & 0.000 \\
\hline 4 & $\begin{array}{c}\text { Human resources } \\
\mathrm{R}^{2}=0.256, \mathrm{p}=0.259\end{array}$ & 0.360 & 5.224 & -0.003 & -0.050 & 0.196 & 2.873 & 0.000 \\
\hline 5 & $\begin{array}{c}\text { Material resources } \\
\mathrm{R}^{2}=0.279, \mathrm{p}=0.005\end{array}$ & 0.386 & 5.800 & -0.022 & -0.353 & 0.208 & 3.113 & 0.000 \\
\hline 6 & $\begin{array}{l}\text { Tools and equipment } \\
\mathrm{R}^{2}=0.272, \mathrm{p}=0.015\end{array}$ & 0.337 & 4.905 & -0.012 & -0.188 & 0.166 & 2.410 & 0.000 \\
\hline
\end{tabular}

Table 2:- Regression analysis to predict the dependent variable 


\section{DISCUSSION OF THE FINDING}

The purpose of the study is to investigate available resources and workshop practices as a correlate between Electrical Installation and Maintenance Work students' behaviour and entrepreneurial intentions. The core contribution of this study is based on the fact the previous studies of behavioural mediators and available resources considered access to tools and equipment, material resources, business climate etc (Ohanu et al. 2020) but this study expand the result of previous studies with clear research into the influence of workshop safety and education and guided maintenance operations. In the previous study human resources was insignificant, financial resources was partially accepted, material resources was insignificant, whereas all the available school resources and workshop practices have significant influence on entrepreneurial intentions. This is an indication that adequate training on safety education and guided maintenance could actually aggravate electrical installation and maintenance works students' behaviour to establish either a maintenance firm or a safety operation firm. Also, available school resources are interlinked with students' access to resources. In reality, due to lack of most of infrastructures and laboratory/workshop tools and equipment with the presence of skilled and professional human resources in our technical colleges, students are therefore motivated to own their personal tools and equipment and sometimes their materials during practical sections whereas this can be achieved with students access to adequate financial resources (Verma and Mann, 2007; Danes and Haberman, 2007).

\section{CONCLUSION}

Based on the purpose of the study, conclusions were drawn from the result of the findings that financial resources, human resources, tools and equipment, material resources, safety practice and education and guided maintenance operations have significant influence on electrical installation and maintenance work students' attitude, subjective norm and perceived behavioural control towards entrepreneurial intentions. The result of the study is limited as a result of the sample size, which implies that the result may be altered with an increase in the sample size which can influence the degree of the responses.

\section{$>$ Implication of the study}

The benefits that accrued from the findings of this study shall have theoretical and practical significance. Theoretically, the study will add to the existing theory of planned behaviour. It will establish a theoretical framework that can be relied on when designing measures to investigate the behavioural factors and resources that influence entrepreneurial intentions.

Practically, this study is beneficial to the following: students, teachers, technical institutions, parents/society, and government.
Students in general education and technical schools will benefit from this study, the findings will make them aware of their internal force/energy/motive called entrepreneurial intentions and the various ways in which their intentions can be turned realities. Also, it will assist them to utilize effectively their available resources (human, material, financial, etc) to achieve their intentions to become a great entrepreneur of their desires.

Technical teachers and teachers in general education will also benefit from the findings of this study. It will keep them abreast of the knowledge of their role models, to build, to nurture and to stir up inert ideas in their students. As a result of this, many students will pick up entrepreneurial intentions as a result of their teacher's behaviour or attitude, appearance, activeness and hardworking habit. Not only this but also to manipulate the available resources in practical work so that students' can attain their intentions.

Technical institutions will receive a limelight from the result of this study. They will be motivated to move to bridge the gap between theory and practice. As a result of this, they can seek appropriate collaboration between private institutions and Non - governmental organizations to provide the necessary facilities needed to carry out teaching-learning process. It will also enhance technical institutions to seek collaboration between industries and institutions so that students can have the required knowledge to stir up the right entrepreneurial ideas.

Parents and the entire society will learn a lesson from the result of this study as it will help to change the societal misconceptions about technical education entrepreneurs. Like many view technical education as education for the less privilege, the never do well eland the mentally retarded. So this study seeks to change the poor public perception as a result of the outcome of great entrepreneurial intentions which had been achieved. Many parents discourage the child (ren) from venturing into technical education entrepreneurship as a result of these perceptions whereby their wards entrepreneurial intentions are cut off. With this study, it will be revealed that technical education entrepreneurship is capital intensive, expensive, and meant for the brilliant people who can strive or compete in the entrepreneurial market.

The government will receive a bearing on how and where to channel the course of education in the country. It will stir the government to invest more in technical education to stimulate entrepreneurial intentions in students in technical colleges and motivates the students in general education to continue in entrepreneurship as it has been introduced in the secondary education curriculum. Also, it will be a point light to them to create a viable economy so that young entrepreneurs can succeed in their choice of career. 


\section{REFERENCES}

[1]. Ajzen, I. (1991) The Theory of Planned Behaviour. Organizational Behaviour and Human Decision Processes, 50(2), 179-211

[2]. Ana, T. M, Makedonka, D., and Jadranka, M. (2016) Drivers of Entrepreneurial Intentions Among Business Students in Macedonia, Economic Research Ekonomska Istraživanja, 29(1), 1062 - 1074.

[3]. Aragon-Sanchez A., Baixauli-Soler S., and CarrascoHernandez A. J. (2017). A missing link: the behavioral mediators between resources and entrepreneurial intentions. InternationalJournal of Entrepreneurial Behavior \& Research, 23(5), 752768.

[4]. Armstrong, S. J., and Hird, A. (2009) Cognitive style and entrepreneurial drive of new and mature business owner-managers. Journal of Business Psychology, 24(4), 419-430.

[5]. Baron, R.A. (2004) The Cognitive Perspective: A Valuable Tool for Answering Entrepreneurship's Basic "Why" Questions. Journal of Business Venturing, 19(2), 221-239.

[6]. Danes, S.M., and Haberman, H.R. (2007). Teen Financial Knowledge, Self-Efficacy, and Behavior: A Gendered View. Financial Counseling and Planning, 18(2), 48-60.

[7]. Eriki, O. P. and Anthony, I. (2009) Capacity of SMEs in Nigeria to Access Institutional Equity Finance. Research Journal of Business Management. 3(1) 1 5.

[8]. Federal Republic of Nigeria (2004). National Policy on Education (Revised Ed.). Lagos: Nigeria Education Research and Development Council (NERDC) Press.

[9]. Gartner, W.B. (1989) "Who is an Entrepreneur?" is the Wrong Question. Entrepreneurship: Theory and Practice, Summer: pp $47-68$.

[10]. Guerrero, M., Rialp, J. and Urbano, D. (2008). The Impact of Desirability and Feasibility on Entrepreneurial Intentions: A Structural Equation Model. International Entrepreneurship \& Management Journal, 4, 35-50.

[11]. Gupta, V. K, Turban, D. B, Wasti, S. A and Sikdar, A. (2009) The Role of Gender Stereotypes in Perceptions of Entrepreneurs and Intentions to become an Entrepreneur. Entrepreneurship: Theory and Practice, 33(2) 397 - 417.

[12]. Hattab, H. W. (2014). Impact of Entrepreneurship Education on Entrepreneurial Intentions of University Students in Egypt. The Journal of Entrepreneurship, 23(1), $1-18$.

[13]. Holmgren, C., and From, J. (2005) Taylorism of the Mind: Entrepreneurship Education from a Perspective of Educational Research. European Educational Research Journal, 4(4), 382-390.

[14]. Krueger, N. F, and Carsrud, A. L. (1993) Entrepreneurial Intentions: Applying the Theory of Planned Behaviour. Entrepreneurship \& Regional Development, 5(4), 315-330.
[15]. Marjan, J.G., Ute, S., Mariola, L., and Juan, A.M. (2018) Predicting Entrepreneurial Career Intentions: Values and the Theory of Planned Beahviour. Journal of Career Assessment, 26(3) 457 - 475.

[16]. Mumtaz, B.A., Munirah, S., and Halimahton, K (2012) The Relationship Between Eduational Support and Entrepreneurial Intentions in Malaysian Higher Learning Institution. Procedia - Social and Behavioural Sciences, 69:2164 - 2173

[17]. National Board for Technical Education (2003) Electrical Installation and Maintenance Works Curriculum and Course Specifications. Kaduna: NBTE Publication.

[18]. Ohanu, I.B. and Chukwuone, C.A. (2018). Constraints to the use of online platform for teaching and learning technical education in developing countries. Education and Information Technologies, 23(6),3029 $-3045$

[19]. Ohanu, I.B. and Ogbuanya, T.C. (2018) Determinant Factors of Entrepreneurship Intentions of Electronic Technology Education Students in Nigerian Universities. Journal of Global Entrepreneurship Research, 8(36), 1-17.

[20]. Ohanu, I.B., Shodipe, O.T., Chukwu, D. U. and Chukwuma, J.N. (2020) Impact of behavioural factors as related to available resources on entrepreneurial intentions of electrical installation and maintenance work students. International Journal of Engineering Education. 36(1A) $142-154$.

[21]. Ozaralli, N. and Rivenburgh, N.K. (2016) Entrepreneurial Intention: Antecedents to Entrepreneurial Behaviour in the U.S.A and Turkey. Journal of Global Entrepreneurship Research 6(3) 1 32.

[22]. Peng, X., Lu, G., and Kang, H. (2012) Entrepreneurial intentions and its influencing factors: A Survey of the University Students in Xi'an China. Creative Education, 3, 95-100.

[23]. Sedgwick, P. (2015) Multistage Sampling. DOI: 10.1136/bmj.h4155

[24]. Thompson, E.R. (2009) "Construct Clarification and Development of an Internationally Reliable Metric". Entrepreneurship Theory and Practice, 33(3), 669694.

[25]. Verma, A., and Mann, S. (2007). Learning among lower wage and at-risk workers: The roles of personal, organizational, and social resources. Canadian Journal forthe Study of Adult Education, 20, 114-129.

[26]. Trading Economics (2019) Unemployment Rate in Africa. Accessed January 19, 2019 from: https://tradingeconomics.com/countrylist/unemployment-rate?continent=africa. 